\title{
MULTI-ENVIRONMENTAL EVALUATION FOR GRAIN YIELD AND ITS COMPONENTS OF QUINOA GENOTYPES ACROSS THE NORTH WESTERN COAST OF EGYPT
}

\author{
El-Sadek, Ashraf N.
}

Plant Production Department, Ecology and Dryland Agriculture

Division, Desert Research Center, El Mataria, Cairo 11753, Egypt

$$
\begin{aligned}
& \text { multi environmental trial involving five quinoa genotypes } \\
& \text { i.e., KVL-SRA2, KVL-SRA3, Regalona, Q-37 and Q-52 } \\
& \text { was conducted along the North Western Coast of Egypt. }
\end{aligned}
$$

The eight tested environments included two sites in the first season of 2014/2015 i.e. irrigated Matrouh and rainfed Matrouh, while in the second season of 2015/2016 there were six sites including three rainfed sites of Ras El Hekma, El Neguilla and Matrouh as well as an irrigated site in Matrouh with three planting dates i.e., 1 Nov.,15 Nov., and 1 Dec. Grain yield was significantly influenced by both genotypes and environments; Regalona genotype produced the highest grain yield in most of the studied environments ( 6 out of 8 environments) with the highest grain yield of $3.08 \mathrm{t} / \mathrm{ha}$ in irrigated Matrouh site in the first season. Moreover, it showed more drought tolerance as compared to the other genotypes. The environment effect was the major source of variation as compared to the genotype and genotype $\times$ environment interaction effects, and attributed to $88.5 \%$ of the total variation in the grain yield. Two-mode pattern analysis of the environment-standardised matrix of grain yield revealed three genotypic groups of different response pattern across environments. In general, the grain yields of the genotypes were lower under rainfed conditions as compared to irrigated conditions, except for Matrouh in the second season for the late irrigated planting dates i.e., 15 Nov. and 1Dec. The high tolerance of quinoa to drought makes it an excellent choice for the diversification of future agriculture in the North Western Coast of Egypt and other regions with similar harsh conditions.

Key words: Quinoa, rainfed, Genotype $\times$ environment interaction, pattern analysis, principal component analysis 
Archeological excavation suggested that the quinoa originated in the area surrounding Lake Titicaca in Peru and Bolivia. It was cultivated about 5000 years B.C. (Abugoch, 2009). Quinoa has been grown for centuries in Andean region of Bolivia, Peru, Ecuador, Colombia, northwest Argentina and Chile. Inca people call it the mother grain. Its grains have a high protein content (14-16\%) with excellent amino acid balance (Gonzalez et al., 2012) and a wide range of vitamins and minerals (Valencia-Chamorro, 2003). The Food and Agriculture Organization of the United Nation has declared the year 2013 as the international year of quinoa (FAO, 2013) due to its potential contribution to the fight against hunger and malnutrition.

There is always an interest in developing alternative crops to be grown in marginal environments. This is because major cereal crops are progressively failing to produce satisfied yield under salinity and scarce water resources in these environments. Quinoa (Chenopodium quinoa Willd.) is known as a high quality grain crop and a well adapted crop to marginal areas (Choukr-Allah et al., 2016). These areas suffer from one or more of the abiotic stresses (drought, high temperature and salt). For these reasons, the crop is attractive to be cultivated in the arid and semi arid regions. Quinoa's tolerance of drought stress was confirmed by Geerts et al. (2008a and b) and Martinez et al. (2009), who found non-significant differences in grain yield of quinoa plants of the Santa Maria and K'ellu varieties on the plateau of Bolivia, when subjected to different irrigation regimes (full irrigation and irrigation deficit). Likewise, Koyro and Eisa (2008) concluded that the quinoa plants could survive and complete its life cycle under the highest concentration of $\mathrm{NaCl}$ of $500 \mathrm{~mol} \mathrm{~m}^{-3}$ (sea water salinity). In the same study and at the highest level of salinity i.e., $500 \mathrm{~mol}$ $\mathrm{m}^{-3}$, total fresh and dry weight of grains was decreased; however it increased the water and ash contents as well as the protein content.

Quinoa reacts to drought in several ways; drought avoidance by reducing the transpiration rate as a result of decreasing the stomatal conductance and by sustaining water uptake (Razzaghi et al., 2011 and Stikić et al., 2015). They concluded that quinoa should be irrigated when or before the relative available water reaches 0.42 . In a study by Razzaghi et al. (2012), two irrigation treatments were used i.e., 95\% of field capacity and non-irrigated (progressive drought). Results showed that the drought and salinity stresses did not affect the dry matter production. Grain yield decreased by $33 \%$ under the highest salinity concentration of $40 \mathrm{ds} / \mathrm{m}$ as compared to the control $(0 \mathrm{dS} / \mathrm{m})$. However, the drought stress caused a slightly low reduction in grain yield by $8 \%$. They concluded that increasing the salinity level from 20 to $40 \mathrm{dS} / \mathrm{m}$ did not affect the grain yield. In Matrouh and under rainfed conditions, Shams (2011) evaluated quinoa growth and yield under land preparation systems and supplementary irrigation. Three treatments of irrigation (rainfall only, rainfall + one

Egyptian J. Desert Res., 67, No. 1, 65-82 (2017) 
supplementary irrigation and rainfall + two supplementary irrigations) and two methods of land preparation (seeding on a flat land and seeding on ridges). The results showed that there was an increase in grain yield and plant height by increasing supplementary irrigation. The highest grain yield of $959 \mathrm{~kg} / \mathrm{ha}$ was obtained by giving the plants two supplemental irrigations and the cultivation in a flat land.

Choice of quinoa variety is usually determined by the length of the growing season. In regions characterized by short growing season, the most suitable quinoa cultivars must combine favorable earliness and yield characters. However, for yield maximization strategies, it is important to remember that within the high genetic diversity of the species, it is possible to identify the most suitable variety for each study site. Quinoa grain yield and drought stress development can vary significantly according to the genotype. The drought sensitivity of two quinoa varieties i.e., Titicaca and Achachino was evaluated (Sun et al., 2014). It was concluded that Titicaca was more sensitive to progressive drought than Achachino, which resists drought by slowing the growth rate, reducing the leaf area and lowering the stomatal conductance. The environmental variation generated by climatic and topographical range creates a need for genotypes with different characteristics (Bertero et al., 2004). As a result of this, the varieties exhibit a strong variability in the response of the cultivars to the variable environments i.e., large genotype $\mathrm{x}$ environment interaction. Globally, FAO evaluated the performance of 21 quinoa genotypes in 26 countries representing 19 agrarian systems. Results indicated that landraces Q21 and Q26 were more stable with a satisfactory yield ( $>1 \mathrm{t} / \mathrm{ha}$ ) across the different environments (Bazile et al., 2016). The genotype by environment interaction is analyzed by statistical methods to describe G x E data (van Eeuwijk et al., 2005). The variance components estimated from the combined analysis of variance in conjunction with patterns analysis, clustering and ordination. Williams (1976) has been used to predict the response to selection across the environments. A higher variance contribution of $\mathrm{G} \times \mathrm{E}$ effect as compared to genotype effect was recorded in quinoa (Curti et al., 2014).

Climate data are the main factors to decide the sowing date, and to understand the best position in the crop calendar for water use efficiency and to avoid high temperatures, especially at the flowering stage, therefore, quinoa is considered a winter crop in Egypt (Bazile et al., 2016). In Egypt, Shams et al. (2011) studied the effect of four sowing dates of quinoa i.e., 15 Nov., 15 Dec., 1 Feb. and 15 Feb. The results showed that there was a gradual reduction in grain yield per feddan with delaying time of sowing till mid of February. Reduction of grain yield between the first and latter dates was estimated to be $60 \%$. While, in southern Morocco, Hirich et al. (2014) tested ten sowing dates for quinoa from $1^{\text {st }}$ of November up to March $15^{\text {th }}$. The sowing date highly affected the growth and yield of quinoa due to the 
different climate variables. The study concluded that, the earlier the sowing date (November to early December), the higher the grain yield.

The objectives of this study were; 1) to improve our knowledge about quinoa as a multi-purpose crop , 2) to examine whether the crop can be grown for its full growth potential under the rainfed conditions in the North Western Coast of Egypt, 3) to examine the performance of five quinoa genotypes in eight environments resulting from a combination of different locations, years, water regimes and planting dates and finally 4) to group quinoa genotypes according to the relative response across environments for their grain yield.

\section{MATERIALS AND METHODS}

\section{Genotypes and Testing Environments}

A set of five quinoa genotypes was evaluated in 8 environments across the North Western Coast of Egypt. The eight environments (Table 1) were a combination of two sites in the first season of 2014/2015 i.e. irrigated Matrouh and rainfed Matrouh, while in the second season of 2015/2016, three rainfed sites of Ras El Hekma, El Neguilla and Matrouh as well as an irrigated site in Matrouh with three planting dates i.e., 1 Nov., 15 Nov. and 1 Dec. were cultivated. The experimental sites were located in farmers' fields (all sites under rainfed conditions) to better understanding the potentiality of quinoa to grow under rainfed conditions and an experimental research station belonging to the Sustainable Development Center for Matrouh Resources, Applied Research Center (SDCMR;ARC) in which the irrigated quinoa was grown. The selected sites were different in regard to the total rainfall amount and distribution; however they were sharing the same soil texture of sandy clay loam. The selected only available quinoa genotypes were KVL-SRA2, KVL-SRA3, Regalona,Q-37 and Q-52 and were provided by the Desert Research Center. These genotypes represent a wide range of genetic diversity according to biochemical and molecular markers (Omar et al., 2014).

\section{Field Experiments}

In each environment, a randomized complete block design with three replicates was used. Plot size was 6 rows, $4 \mathrm{~m}$ long with an inter-row spacing of $0.5 \mathrm{~m}$ and $25 \mathrm{~cm}$ between plants. During the two growing seasons, no fertilizers were used as followed by the local farmers. Plant height $(\mathrm{cm})$, stem diameter $(\mathrm{mm})$ and panicle length $(\mathrm{cm})$ were measured for ten plants from the 4 central rows; grain, straw and biological yields (t/ha) were obtained for each plot in all experiments. Harvest index (\%) was calculated as the ratio of the grain yield to the total above-ground biomass at harvest. The weight of 1000-grain (g) was determined using three replicates of 1000 grains from the harvest grains of each plot.

Egyptian J. Desert Res., 67, No. 1, 65-82 (2017) 
Table (1). Coordinates, planting date, harvesting date and rainfall for the studied locations.

\begin{tabular}{|c|c|c|c|c|c|c|c|}
\hline \multirow[t]{2}{*}{ Season } & \multirow[t]{2}{*}{ Location } & \multicolumn{2}{|c|}{ Coordinates } & \multirow{2}{*}{$\begin{array}{l}\text { Planting } \\
\text { date }\end{array}$} & \multirow{2}{*}{$\begin{array}{c}\text { Harvesting } \\
\text { date }\end{array}$} & \multirow{2}{*}{$\begin{array}{c}\text { Mean } \\
\text { daily } \\
\text { temp. } \\
\left(\mathrm{C}^{\circ}\right)\end{array}$} & \multirow{2}{*}{$\begin{array}{c}\text { Rainf } \\
\text { all } \\
(\mathbf{m m})\end{array}$} \\
\hline & & Latitude & Longitude & & & & \\
\hline \multirow[t]{2}{*}{$2014 / 2015$} & Matrouh & $31.17^{\circ} \mathrm{N}$ & $27.40^{\circ} \mathrm{E}$ & $25 / 10 / 2014$ & $29 / 3 / 2015$ & 18.10 & 81.60 \\
\hline & SDCMR, ARC & $31.35^{\circ} \mathrm{N}$ & $27.18^{\circ} \mathrm{E}$ & $01 / 12 / 2014$ & $15 / 4 / 2015$ & 16.62 & 81.60 \\
\hline \multirow[t]{6}{*}{$2015 / 2016$} & Ras El Hekma & $31.08^{\circ} \mathrm{N}$ & $27.68^{\circ} \mathrm{E}$ & 09/11/2015 & $01 / 4 / 2016$ & 16.37 & 219.4 \\
\hline & El Neguilla & $31.44^{\circ} \mathrm{N}$ & $26.62^{\circ} \mathrm{E}$ & $01 / 2 / 2016$ & $14 / 5 / 2016$ & 17.87 & 161.9 \\
\hline & Matrouh & $31.17^{\circ} \mathrm{N}$ & $27.40^{\circ} \mathrm{E}$ & $31 / 10 / 2015$ & $02 / 4 / 2016$ & 17.04 & 230.0 \\
\hline & SDCMR, ARC & $31.35^{\circ} \mathrm{N}$ & $27.18^{\circ} \mathrm{E}$ & $01 / 11 / 2015$ & $07 / 4 / 2016$ & 17.23 & 230.0 \\
\hline & SDCMR, ARC & $31.35^{\circ} \mathrm{N}$ & $27.18^{\circ} \mathrm{E}$ & $15 / 11 / 2015$ & $13 / 4 / 2016$ & 17.23 & 230.0 \\
\hline & SDCMR, ARC & $31.35^{\circ} \mathrm{N}$ & $27.18^{\circ} \mathrm{E}$ & $01 / 12 / 2015$ & $19 / 4 / 2016$ & 16.62 & 230.0 \\
\hline
\end{tabular}

SDCMR, ARC: Sustainable Development Center of Matrouh Resources, Applied Research Center. Mean temperature and rainfall are for the period from sowing to harvesting.

\section{Statistical Analysis}

The average data were subjected to Analysis of Variance (ANOVA) using CropStat version 7.2 statistical software (CropStat, 2009). Also, Eberhart and Russell (1966) model was used as a stability analysis because it is a widely used, simple and convenient model to calculate the genotypic stability.

\section{Eberhart and Russell (1966) model}

$y i j=\mu i+\beta i I j+\delta i j$

where yij is the adjusted mean phenotypic value for the $i$ th line at the $j$ th environment, $\mu i$ is the overall mean of $i$ th line, $\beta i$ is the regression coefficient from the ERR (estimated as B, the ERR stability index), $I j$ is the environmental index, and $\delta i j$ is the residual error.

This statistical method has two indices to measure the genotypes stability across different environments i.e., Regression coefficient $\left(b_{i}\right)$ and Variance of the regression deviations $\left(S^{2} d_{i}\right)$.

Principal Component Analysis (PCA) was used to classify quinoa genotypes and to display the genotype by environment interaction through the biplot. Pattern analysis (complementary use of clustering and ordination; Williams (1976) was applied to the environment-standardized (Fox and Rosielle, 1982) array of $\mathrm{G} \times \mathrm{E}$ interaction for grain yield. For the classification, a hierarchical agglomerative clustering method with incremental sum of squares (Ward, 1963) as the fusion criterion was utilized.

The Euclidean distance was used as dissimilarity measure for Ward's method. A dendrogram was constructed on the basis of fusion level to 
investigate similarities in terms of genotype-specific responses to environments) and environments (in terms of the way they influence the relative performance of the genotypes). Both cluster analysis and PCA were performed using Microsoft Excel 2013/XLSTATc-Pro (Version 2015.6.01.23953, 2015, Addinsoft, Inc., Brooklyn, NY, USA).

\section{RESULTS AND DISCUSSION}

\section{Climate Characteristics}

The climate of the study sites are typical of dry Mediterranean area. The climatic conditions were somewhat different in term of rainfall amount and distribution, in the first year the amount of rain was $80.61 \mathrm{~mm}$ however in the second season it ranged from $161.94 \mathrm{~mm}$ in El Neguilla to $230 \mathrm{~mm}$ in Matrouh, which significantly influenced the growth and yield of quinoa genotypes. Other climate factors that are affecting the growth of quinoa is the photoperiod with genotypes less sensitive to photoperiod originating from the sea level of southern Chile (Jacobsen, 2003) as compared to high photoperiod sensitive genotypes originating from the tropics (Bendevis et al., 2014). Temperature is also reported as a very important abiotic factor influencing the growth and yield of quinoa, with a low temperature that is increasing the growing period length (Hirich et al., 2014). Jacobsen and Bach (1998) defined the optimum temperature for quinoa growth as $22^{\circ} \mathrm{C}$ and a base temperature of $3^{\circ} \mathrm{C}$.

\section{Analysis of Variance}

The results of tables (2,3 and 4) show the yield and its components of the five quinoa genotypes grown in eight different environments. In the first season i.e., 2014/2015, Regalona recorded the highest yield and yieldrelated parameters in the two environments i.e., rainfed (E1) and irrigated (E2) Matrouh. However, the highest harvest and crop indices were recorded by Q-52 and KVL-SRA2 genotypes in E1 and E2, respectively.

In the second season of 2015/2016 and under rainfed conditions, Regalona was the superior genotype in two sites i.e., Ras El Hekma (E3) and Matrouh (E5) with a grain yield of 0.56 and $2.38 \mathrm{t} / \mathrm{ha}$, respectively. However, at El Neguilla site (E4) it came second after Q-37 genotype with a grain yield difference of $0.15 \mathrm{t} / \mathrm{ha}$, and it recorded the highest harvest index. Under the irrigated conditions, Regalona genotype surpassed the other genotypes in grain yield in the first and third planting dates. However, in the second planting date, KVL-SRA2 was the superior genotype with a grain yield of $1.84 \mathrm{t} / \mathrm{ha}$ (Table 4$)$.

It is also clear from the results that KVL-SRA2 and Q-52 genotypes were more sensitive to the drought stress as they produced the lowest grain yields under rainfed conditions in both seasons (Tables 2 and 3). The same results were reported by Sun et al. (2014), who concluded that Titicaca

Egyptian J. Desert Res., 67, No. 1, 65-82 (2017) 
variety (Q-52) was more sensitive to drought as compared to Achachino variety and it is more adaptable to humid areas i.e., Denmark (the origin of the variety). Also, they indicated that the Q-52 variety responds to the drought by closing the stomata and also reducing the leaf area to decline the transpiration rate. On the other hand, Regalona proved to be more tolerant to the drought stress due to the fact that it was produced by cross breeding of genotypes from two different sources, one close to the equator (low altitude) and the other one from southern Chilean region ( low levels of rain) (Bazile et al., 2016).

It is worth noting that quinoa genotypes produced lower yield under rainfed conditions as compared to irrigated conditions. An exception was at Matrouh in the second season, where the late planting dates of 15 Nov. and 1 Dec. under irrigated condition produced lower yields than the rainfed location of Matrouh. This could be the result of high rainfall in this location i.e. $230 \mathrm{~mm}$ with a soil characterized by a high water holding capacity, which was sufficient for producing a potential yield of quinoa. Moreover, lower temperature in these two planting dates negatively affected the growth and yield of quinoa. These results are in agreement with those obtained by Maliro et al. (2017).

\section{Eberhart and Russell Model}

According to Eberhart and Russell statistical method (Eberhart and Russell, 1966) for studying the stability of different genotypes grown in a number of environments, a genotype could be considered stable when it has a coefficient of regression $(\mathrm{b} i)=1$ and deviation from regression $S^{2} d_{i}=0$. Based on the data presented in table (5), the coefficient of regression for the studied genotypes ranged from 0.798 to 1.130 . Based on grain yield, Q-52 had a bi value of 1.029 followed by KVL-SRA3 (0.948), which are considered the most stable cultivars (closer to 1) as compared to the other cultivars, while KVL-SRA2 had a bi value of 0.798 and is considered an unstable cultivar.

According to the deviation from regression values, which ranged from 0 to 0.08 , KVL-SRA3 had the lowest value of deviation from regression ( 0 ) followed by Q-37 (0.02), which are considered the most stable cultivars, while KVL-SRA2 had the highest values of deviation from regression (0.08), which can be classified as less stable cultivar compared to the others. The coefficient of determination varied from $2 \%$ recorded by Q52 to $35 \%$ for KVL-SRA3. 


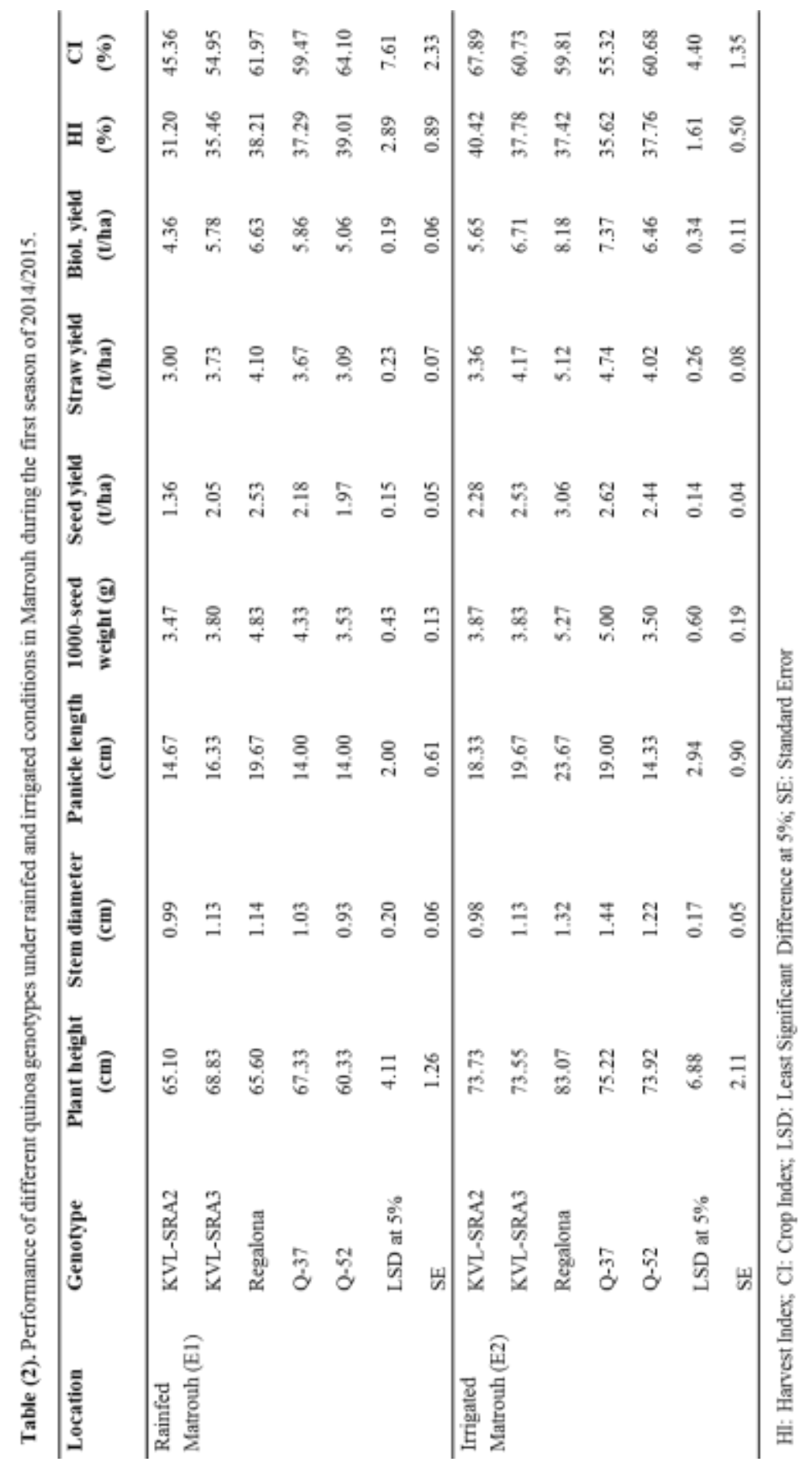

Egyptian J. Desert Res., 67, No. 1, 65-82 (2017) 


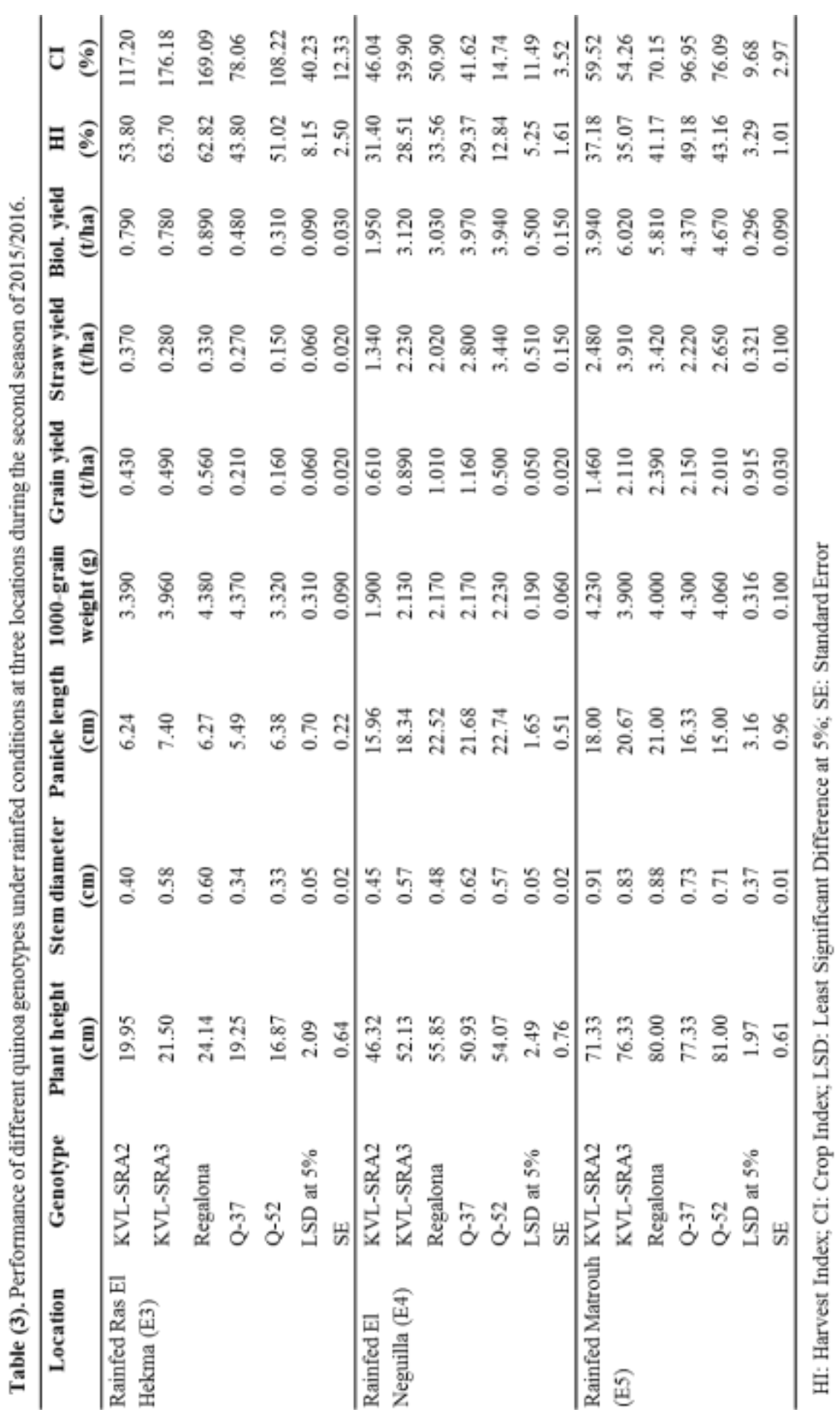

Egyptian J. Desert Res., 67, No. 1, 65-82 (2017) 


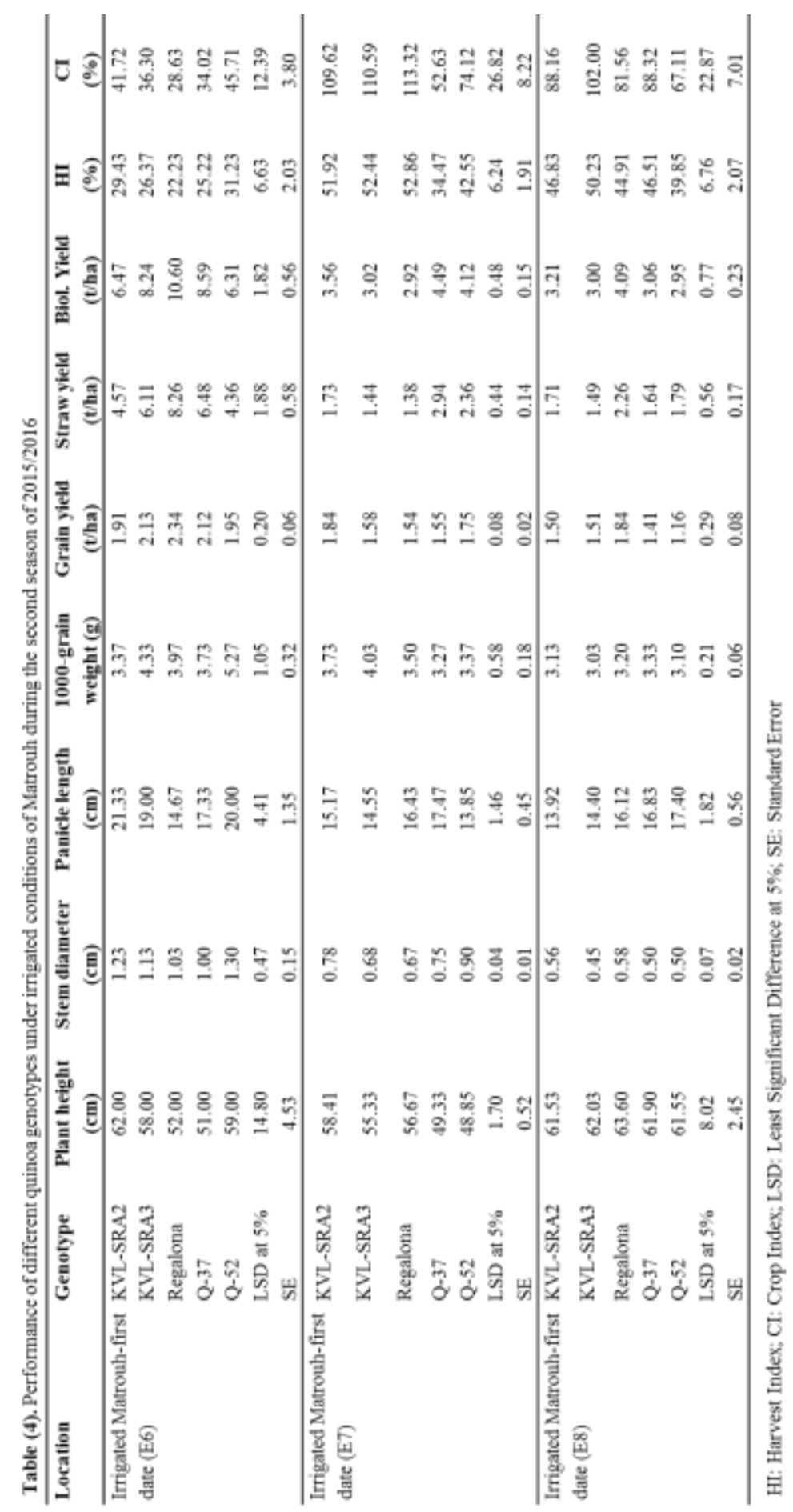

Egyptian J. Desert Res., 67, No. 1, 65-82 (2017) 
Table (5). Stability parameters of quinoa genotypes for the grain yield.

\begin{tabular}{lccccccc}
\hline Genotypes & Mean yield (t/ha) & $\mathrm{b} i$ & $\mathrm{SE}$ & MS-TXL & MS-REG & $\mathrm{S}^{2} \mathrm{~d} i$ & $\mathrm{R}^{2}(\%)$ \\
\hline KVL-SRA2 & 1.42 & 0.798 & 0.145 & 0.09 & 0.15 & 0.08 & 24 \\
KVL-SRA3 & 1.66 & 0.948 & 0.029 & 0 & 0.01 & 0 & 35 \\
Regalona & 1.91 & 1.13 & 0.099 & 0.04 & 0.06 & 0.04 & 22 \\
Q-52 & 1.68 & 1.029 & 0.089 & 0.03 & 0 & 0.03 & 2 \\
Q-37 & 1.49 & 1.095 & 0.075 & 0.02 & 0.03 & 0.02 & 21 \\
\hline
\end{tabular}

Where; $b i$ is the regression coefficient, MS-TXL is contribution of each cultivars to interaction MS. MS-REG is the contribution of each cultivar to the regression component of the cultivar by location interaction, $\mathrm{S}^{2} \mathrm{~d} i$ is the regression deviation mean square, $\mathrm{R}^{2}$ is the coefficient of determination.

\section{Genotype and Genotype $\times$ Environment Interaction for Grain Yield}

The environment effect was the major source of variation and attributed to $88.5 \%$ of the total variation in the grain yield. Genotypes and genotype $\mathrm{x}$ environment interaction accounted only for 5.46 and $6.06 \%$, respectively from the total variation. The AMMI analysis of variance showed that only the first IPC was highly significant $(P<0.01)$ (Table 6).

The yield data was represented in a bi-plot (Fig. 1) for finding a lower dimensional pattern from high dimension data. The first two principal components of the data explained $91.38 \%$ from the total variation of the yield. The angle between the environmental vectors ranged from small positive values to values close to $180^{\circ}$ (Fig. 1), which suggests that the associations between environments in terms of the influence on the grain yield ranged from strongly positive and strongly negative. The angle between Matrouh environments i.e., two rainfed sites (E1 and E5) and two irrigated sites (E2 and E6) is smaller than $90^{\circ}$, which suggests that, in each group, the two environments are similar in the way they discriminate among the genotypes. Similar pattern was observed between the vectors of E3 and E8 environments. A wide angle was found between E7 and the other environments suggesting that the performance of the quinoa genotypes in this environment was different as compared to other environments in terms of their grain yield.

The length of the vector reflects the discriminative ability of the environment. In this context, E3 and E8 environments were the best discriminative environments for investigated genotypes as they had longer vectors (Yan and Hunt, 2001). On the other hand, E4 had the shortest vector length suggesting that this environment is not a discriminative environment for the genotypes. Regalona showed a positive correlation to E2 and E6, however it had a negative correlation with E7 in which KVL-SRA2 was the superior genotype. 
Table (6). Analysis of variance for the AMMI model.

\begin{tabular}{lccccc}
\hline Source & D.F. & S.S. & M.S. & F & Prob. \\
\hline Genotypes & 4 & 1.135630 & 0.283908 & & \\
Environments & 7 & 18.376900 & 2.625260 & & \\
Genotypes $\times$ Environment & 28 & 1.259060 & 0.045000 & & \\
AMMI Component 1 & 10 & 0.882083 & 0.082000 & 4.212 & 0.004 \\
AMMI Component 2 & 8 & 0.201373 & 0.025200 & 1.433 & 0.291 \\
AMMI Component 3 & 6 & 0.144346 & 0.024100 & 3.079 & 0.148 \\
AMMI Component 4 & 4 & 0.031257 & 0.007810 & & 1.000 \\
\hline Total & 39 & 20.77150 & & & \\
\hline
\end{tabular}

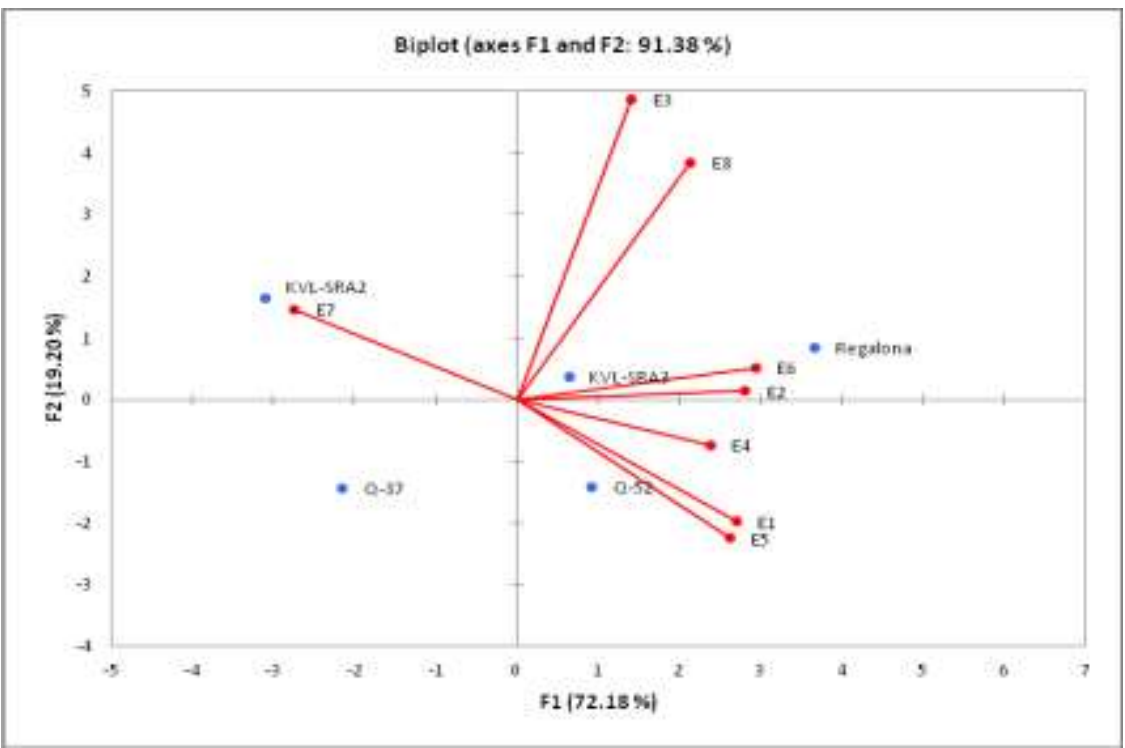

Fig. (1). Biplot of the $1^{\text {st }}$ and $2^{\text {nd }}$ principal components for grain yield of five quinoa genotypes grown in eight environments.

\section{Pattern Analysis for Grain Yield}

Cluster analysis of the environment-standardised matrix of grain yield showed that the five evaluated genotypes could be separated into three groups of different response patterns across environments (Fig. 2). The group of Q-52, KVL-SRA3 and Q-37 was the last to join on the dendrogram, with average yield of $1.68,1.66$ and $1.49 \mathrm{t} \mathrm{h}^{-1}$, respectively. The second group consisted of Regalona with a mean yield of $1.91 \mathrm{t} \mathrm{h}^{-1}$. KVL-SRA2 was in a separate group with a mean yield of $1.42 \mathrm{t} \mathrm{h}^{-1}$. The classification of environments for grain yield gave rise to three groups in the two seasons (Fig. 3). This clustering grossly discriminated between high yield sites (E1,.

Egyptian J. Desert Res., 67, No. 1, 65-82 (2017) 


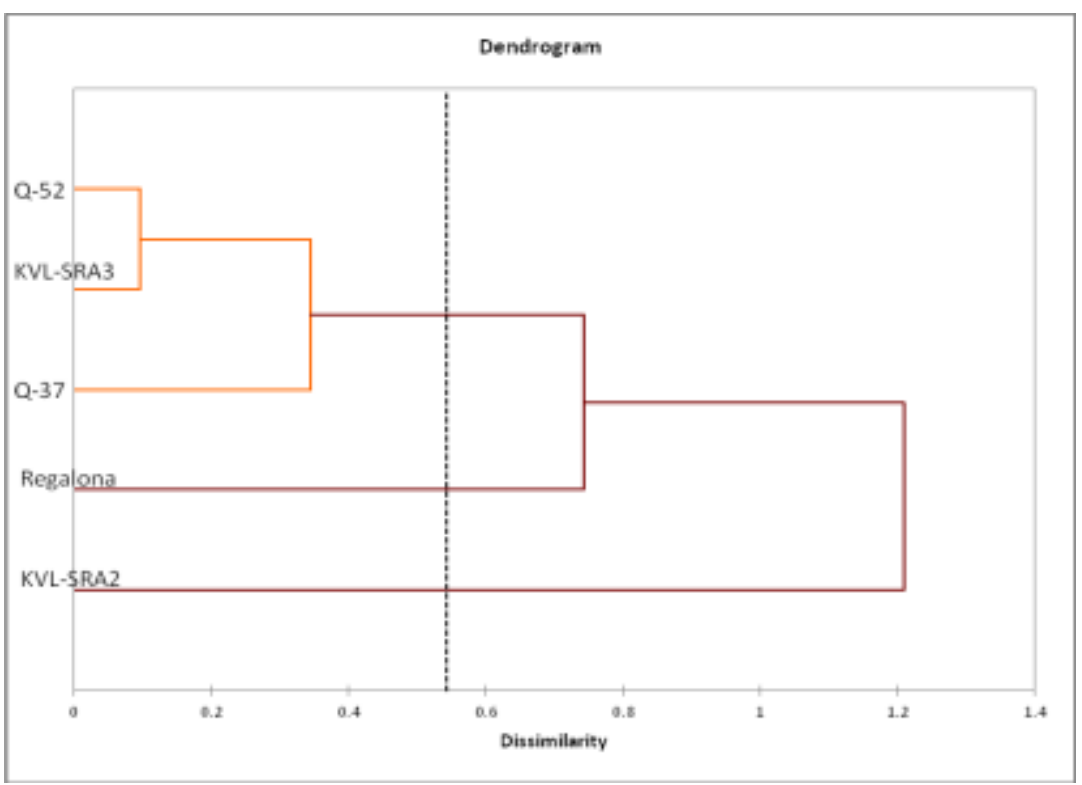

Fig. (2). Hierarchy for the classification of five genotypes of quinoa according to their relative responses for grain yield across eight environments.

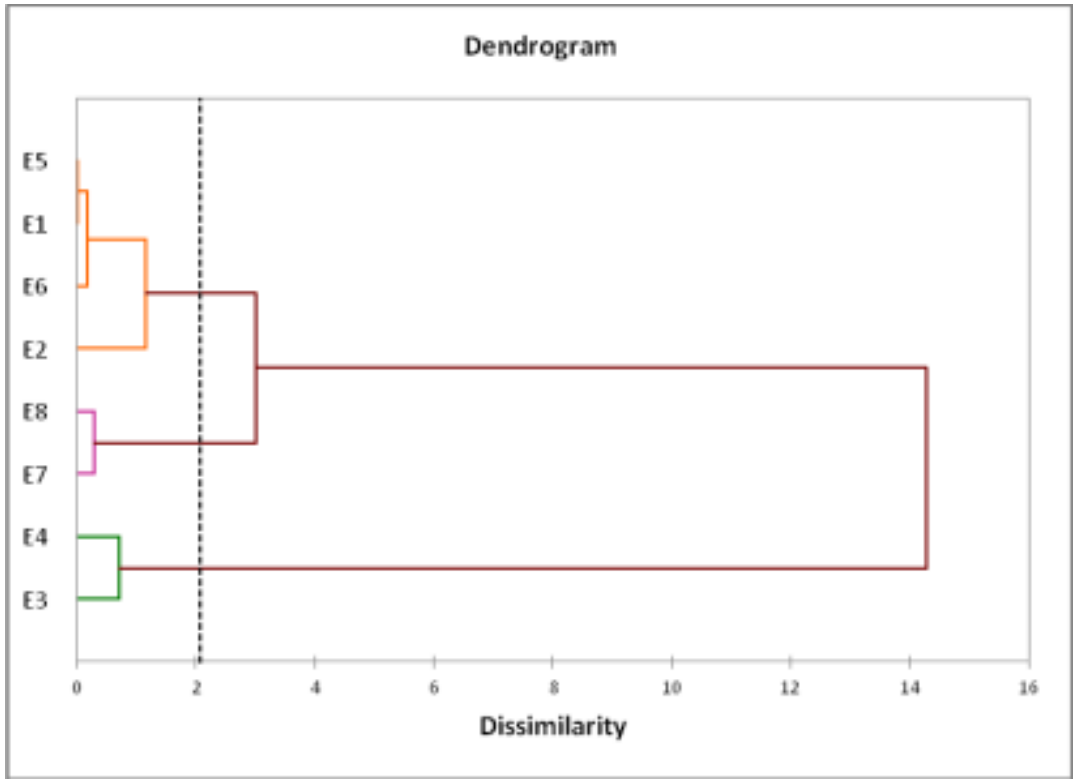

Fig. (3). Hierarchy for the classification of eight environments according to the way they differentiated among patterns of grain yield of five quinoa genotypes.

Egyptian J. Desert Res., 67, No. 1, 65-82 (2017) 
E2, E5, E6) with average yields of 2.02, 2.59, 2.02 and $2.09 \mathrm{t} \mathrm{h}^{-1}$, respectively, moderate yield sites i.e., E7 $\left(1.65 \mathrm{t} \mathrm{h}^{-1}\right)$ and E8 $\left(1.48 \mathrm{t} \mathrm{h}^{-1}\right)$ and low yield sites i.e., E3 $\left(0.37 \mathrm{t} \mathrm{h}^{-1}\right)$ and E4 $\left(0.84 \mathrm{t} \mathrm{h}^{-1}\right)$. The first group included Matrouh site under rainfed (E1) and irrigated (E2) conditions in the first season, and the rainfed Matrouh (E5) and the first planting date of irrigated Matrouh (E6) in the second season. The second group of E7 and E8 included the irrigated Matrouh site in the second and third planting dates, while E3 and E4 were the sites under rainfed condition of Ras El Hekma and El Neguilla characterized with a low grain yield as compared to the other locations

As expected from the domination of the dataset by $\mathrm{G} \times \mathrm{E}$ interaction, no single genotype group was identified to show consistently superior grain yield across all environment groups. The same results were obtained by Bertero et al. (2004), who succeeded to separate the 24 cultivars of quinoa into four groups using the two mode pattern analysis, from mid-altitude valleys of the northern Andes, northern altiplano, southern altiplano and sea level. In the present study, Regalona genotype showed its best performance in the first group of environments (E1, E2, E5, E6). Also, the same genotype produced a better yield in one of the two environments of the other two groups i.e., E3 and E8. In E4 and E7, Regalona recorded the second highest and lowest grain yields, respectively.

In the present study, the presence of genotype $\times$ environment interaction for quinoa grain yield is recorded. This also was previously observed in the same area for other grain crops e.g. wheat (Ali et al., 2015). Since the purpose of the multi-environmental trials is to provide farmers with well adapted and stable cultivars, therefore genotype $\times$ environment interaction can be avoided by better classification of the testing environments to produce sub-environments within which $\mathrm{G} \times \mathrm{E}$ is very low (Zhang et al., 2006) and allows targeting more narrowly adapted cultivars to various sub-environments (Gauch and Zobel, 1997). Results revealed that environments explained most of the total variance reflecting that a wide range of environments was used, also the results suggested the existence of three groups of environments based on the grain yield. Regalona genotype appear to be a widely adapted to most of the studied environments in the North Western Coast of Egypt under both rainfed and irrigated conditions.

\section{CONCLUSION}

Based on the results of the field trials under a wide range of environments in Matrouh, it can be concluded that quinoa could perform well under the low rainfed conditions as compared to other cereal crops i.e., wheat and barley. However, low growth and yield under the high rainfall condition in some locations are unexplainable. Therefore, further 
investigations are needed to study the yield potential of a much wider range of genetically diverse accessions at various soil and water characteristics. Quinoa crop was appreciated by the local farmers as a drought-tolerant and highly nutritional crop, however many studies are needed in regard to the production, harvesting, storage, processing, economics and marketing.

\section{ACKNOWLEDGMENT}

This work has been funded by the Matrouh Sustainable Development Project (MARSADEV), the Italian Ministry of Foreign Affairs, and CIHEAM-Mediterranean Agronomic Institute of Bari (CIHEAM - IAMB).

\section{REFERENCES}

Abugoch, L.E. (2009). Quinoa (Chenopodium quinoa Willd.) composition, chemistry, nutritional, and functional properties. Advanced Food Nutrition Research, 58: 1-31.

Ali, M.B., A. N. El-Sadek, M.A. Sayed and M.A. Hassaan (2015). AMMI biplot analysis of genotype $\times$ environment interaction in wheat in Egypt. Egyptian Journal of Plant Breeding, 19 (6): 1889-1901.

Bazile, D., C. Pulvento, A. Verniau, M.S. Al-Nusairi, D. Ba, J. Breidy, L. Hassan, L.I. Mohammed, M. Mambetov, M. Otambekova, N.A. Sepahvand, A. Shams, D. Souici , K. Miri and N.A. Sepahvand (2016). Worldwide evaluations of quinoa: Preliminary results from post international year of quinoa $\mathrm{FAO}$ projects in nine countries. Frontiers in Plant Science, 7. doi.org/10.3389/fpls.2016.00850

Bendevis, M.A., Y. Sun, S. Shabala, E. Rosenqvist, F. Liu, and S.E. Jacobsen (2014). Differentiation of photoperiod-induced ABA and soluble sugar responses of two quinoa (Chenopodium quinoa Willd.) cultivars. Journal of Plant Growth Regulation, 33 (3): 562-570.

Bertero, H.D., A.J. De la Vega, G. Correa, S.E. Jacobsen and A. Mujica (2004). Genotype and genotype-by-environment interaction effects for grain yield and grain size of quinoa (Chenopodium quinoa Willd.) as revealed by pattern analysis of international multienvironment trials. Field Crops Research, 89 (2): 299-318.

CropStat 7.2 for Windows Tutorial Manual (2009). Crop Research Informatics Laboratory. International Rice Research Institute, 379 pp.

Choukr-Allah, R., N.K. Rao, A. Hirich, M. Shahid, A. Alshankiti, K. Toderich, S. Gill and K.U.R. Butt (2016). Quinoa for marginal environments: toward future food and nutritional security in MENA and Central Asia regions. Frontiers in Plant Science, 7: 346. http://doi.org/10.3389/fpls.2016.00346

Egyptian J. Desert Res., 67, No. 1, 65-82 (2017) 
Curti, R.N., A.J. De la Vega, A. J. Andrade, S.J. Bramardi and H.D. Bertero (2014). Multi-environmental evaluation for grain yield and its physiological determinants of quinoa genotypes across Northwest Argentina. Field Crops Research, 166: 46-57.

Eberhart, S.A. and W.A. Russell (1966). Stability parameters for comparing varieties. Crop Science. 6: 36-40.

FAO (2013). Available online: http://www.fao.org/quinoa-2013/

Fox, P.N. and A.A. Rosielle (1982). Reference sets of genotypes and selection for yield in unpredictable environments. Crop Science, 22 (6): 1171-1175.

Gauch, H.G. and R.W. Zobel (1997). Identifying mega-environments and targeting genotypes. Crop Sci., 37: 311-326.

Geerts, S., D. Raes, M. Garcia, O. Condori, J. Mamani, R. Miranda, J. Cusicanqui, C. Taboada, E. Yucra and J. Vacher (2008a). Could deficit irrigation be a sustainable practice for quinoa (Chenopodium quinoa Willd.) in the Southern Bolivian Altiplano?. Agricultural Water Management, 95: 909-917.

Geerts, S., D. Raes, M. Garcia, J. Vacher, R. Mamani, J. Mendoza, R. Huanca, B. Morales, R. Miranda, J. Cusicanqui and C. Taboada (2008b). Introducing deficit irrigation to stablize yields of quinoa (Chenopodium quinoa Willd.). European Journal of Agronomy, 28: 427-436.

Gonzalez, J.A., Y. Konishi, M. Bruno, M. Valoy and F.E. Prado (2012). Interrelationships among seed yield, total protein and amino acid composition of ten quinoa (Chenopodium quinoa) cultivars from two different agroecological regions. Journal of Science Food and Agriculture, 92: 1222-1229.

Hirich, A., R. Choukr-Allah and S.E. Jacobsen (2014). Quinoa in Morocco effect of sowing dates on development and yield. Journal of Agronomy and Crop Science, 200 (5): 371-377.

Jacobsen, S.E. (2003). The worldwide potential for quinoa (Chenopodium quinoa Willd.). Food Reviews International, 19: 167-177.

Jacobsen, S.E. and A.P. Bach (1998). The influence of temperature on seed germination rate in quinoa (Chenopodium quinoa Willd.). Seed Science Technology, 26: 515-523.

Koyro, H.W. and S.S. Eisa (2008). Effect of salinity on composition, viability and germination of seeds of Chenopodium quinoa Willd. Plant and Soil, 302: 79-90.

Maliro, M.F., V.F. Guwela, J. Nyaika and K.M. Murphy (2017). Preliminary studies of the performance of quinoa (Chenopodium quinoa Willd.) genotypes under irrigated and rainfed conditions of central Malawi. Frontiers in Plant Science, 8. doi: 10.3389/fpls.2017.00227

Martinez, E.A., E. Veas, C. Jorquera, R. San Martın and P. Jara ( 2009). Reintroduction of quinoa into arid Chile: cultivation of two lowland

Egyptian J. Desert Res., 67, No. 1, 65-82 (2017) 
races under extremely low irrigation. Journal of Agronomy and Crop Science, 195: 1-10.

Omar, S.A., I.M. Masoud and R.M.A. Khalil (2014). Genetic evaluation of some quinoa genotypes under Ras Suder conditions. Journal of Plant Production, Mansoura University, 5 (11): 1915-1930.

Razzaghi, F., S.H. Ahmadi, V.I. Adolf, C.R. Jensen, S.E. Jacobsen, M.N. Andersen (2011). Water relations and transpiration of quinoa (Chenopodium quinoa Willd.) under salinity and soil drying. Journal of Agronomy and Crop Science, 197: 348-360.

Razzaghi, F., S.H. Ahmadi, V.I. Adolf, C.R. Jensen, S.E. Jacobsen and M.N. Andersen (2012). Effects of salinity and soil-drying on radiation use efficiency, water productivity and yield of quinoa (Chenopodium quinoa Willd.). Journal of Agronomy and Crop Science, 198: 173184.

Shams, A. (2011). Combat degradation in drought tolerant crop in Egypt. International Journal of Water Resources and Arid Environment, 5: 318-325.

Stikić, R., Z. Jovanović, M. Marjanović and S. Đorđević. (2015). The effect of drought on water regime and growth of quinoa (Chenopodium quinoa Willd.). Ratarstvo Povrtarstvo, 52 (2): 80-84.

Sun, Y., F. Liu, M. Bendevis, S. Shabala and S.E. Jacobsen (2014). Sensitivity of two quinoa (Chenopodium quinoa Willd.) varieties to progressive drought stress. Journal of Agronomy and Crop Science, 200 (1): 12-23.

Valencia-Chamorro, S.A. (2003). In "Quinoa". (Caballero, B. ed.). Encyclopedia of Food Science and Nutrition. Vol. 8. Academic Press, Amsterdam, p. 4895-4902.

van Eeuwijk, F.A., M. Malosetti, X. Yin, P.C. Struik and P. Stam (2005). Statistical models for genotype by environment data: from conventional ANOVA models to eco-physiological QTL models. Crop and Pasture Science, 56: 883-894.

Ward, J.H. (1963). Hierarchical grouping to optimize an objective function. J. Am. Stat. Assoc., 58: 236-244.

Williams, W.T. (1976). In "Pattern Analysis in Agricultural Science". CSIRO, Australia, $340 \mathrm{pp}$.

Yan, W. and L.A. Hunt (2001). Interpretation of genotype $\times$ environment interaction for winter wheat yield in Ontario. Crop Sci., 41 (1): 1925.

Zhang, Y., Z. He, A. Zhang, M. van Ginkel and G. Ye (2006). Pattern analysis on grain yield performance of Chinese and CIMMYT spring wheat cultivars sown in China and CIMMYT. Euphytica, 147 (3): 409-420. 


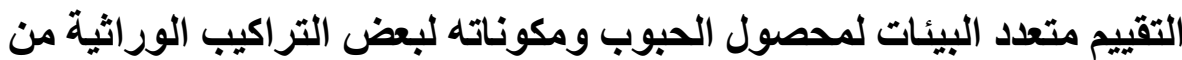 الكينوا على طول الساحل الثمالي الغربي لمصر لئر التري}

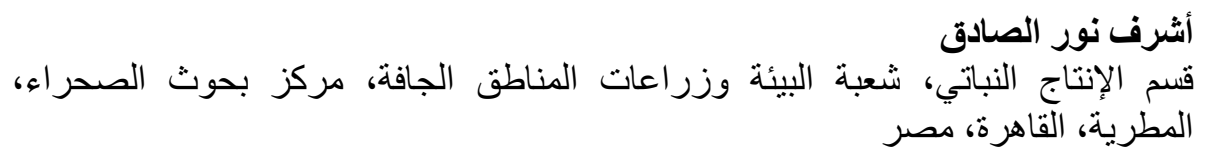

KVL-SRA2, KVL-SRA3, تم تقييم خمسة تراكيب ور اثنة من الكينوا وهي

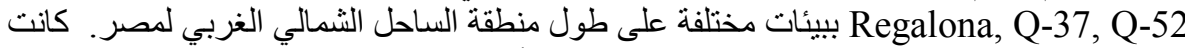

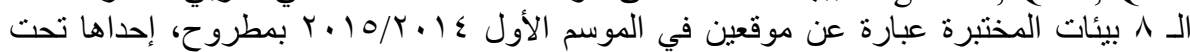

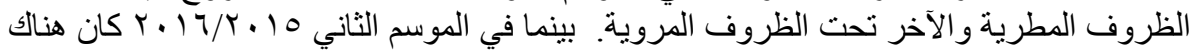

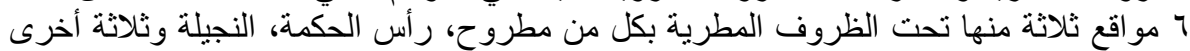

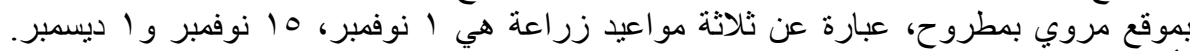

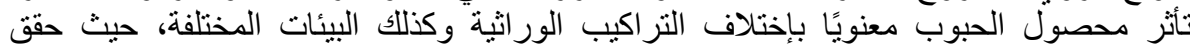

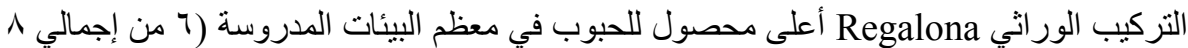

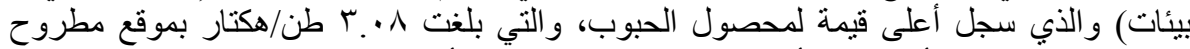

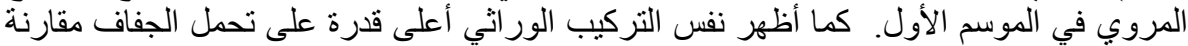

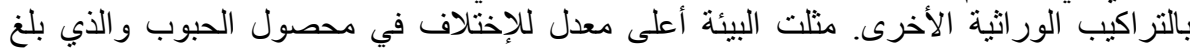

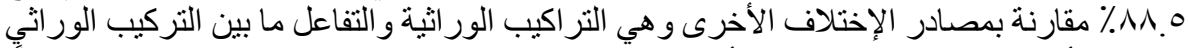

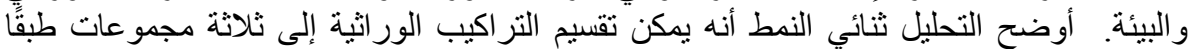

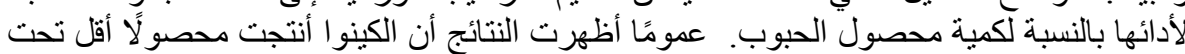

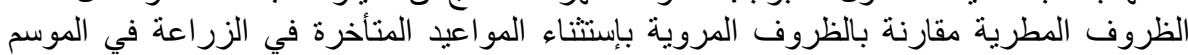

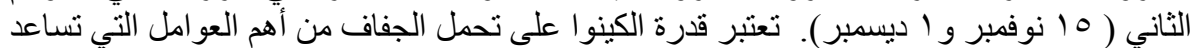

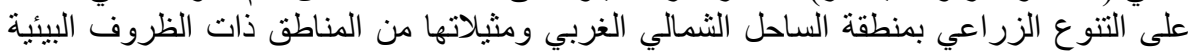
القاسية.

Egyptian J. Desert Res., 67, No. 1, 65-82 (2017) 